\title{
Preparation and Chemical and Physical Characteristics of an Edible Film Based on Native Potato Starch and Nopal Mucilage
}

\author{
David Choque-Quispe ${ }^{1, *(\mathbb{D})}$, Sandro Froehner ${ }^{2}$, Carlos A. Ligarda-Samanez ${ }^{3}{ }^{(\mathbb{D}}$, Betsy S. Ramos-Pacheco ${ }^{1}$, \\ Henry Palomino-Rincón ${ }^{4}$, Yudith Choque-Quispe ${ }^{5}$, Aydeé M. Solano-Reynoso ${ }^{6}$, Fredy Taipe-Pardo ${ }^{4}(0$, \\ Lourdes Magaly Zamalloa-Puma ${ }^{7}$, Miriam Calla-Florez ${ }^{8}$, Miriam E. Obregón-Yupanqui ${ }^{9}$, \\ Miluska M. Zamalloa-Puma ${ }^{7}$ and Antonieta Mojo-Quisani ${ }^{8}$
}

check for updates

Citation: Choque-Quispe, D.;

Froehner, S.; Ligarda-Samanez, C.A.; Ramos-Pacheco, B.S.; Palomino-Rincón, H.; Choque-Quispe, Y.; Solano-Reynoso, A.M.; Taipe-Pardo, F.; Zamalloa-Puma, L.M.; Calla-Florez, M.; et al. Preparation and Chemical and Physical Characteristics of an Edible Film Based on Native Potato Starch and Nopal Mucilage. Polymers 2021, 13, 3719. https://doi.org/10.3390/ polym13213719

Academic Editor: Alexey V. Lyulin

Received: 12 October 2021

Accepted: 22 October 2021

Published: 28 October 202

Publisher's Note: MDPI stays neutral with regard to jurisdictional claims in published maps and institutional affiliations.

Copyright: (C) 2021 by the authors Licensee MDPI, Basel, Switzerland This article is an open access article distributed under the terms and conditions of the Creative Commons Attribution (CC BY) license (https:// creativecommons.org/licenses/by/ $4.0 /)$.
1 Water Analysis and Control Research Laboratory, Universidad Nacional José María Arguedas, Andahuaylas 03701, Peru; bsramos@unajma.edu.pe

2 Department of Environmental Engineering, Universidade Federal do Parana (UFPR), Curitiba 80060-000, Brazil; froehner@ufpr.br

3 Food Nanotechnology Research Laboratory, Universidad Nacional José María Arguedas, Andahuaylas 03701, Peru; caligarda@unajma.edu.pe

4 Agroindustrial Engineering, Universidad Nacional José María Arguedas, Andahuaylas 03701, Peru; hpalomino@unajma.edu.pe (H.P.-R.); ftaipe@unajma.edu.pe (F.T.-P.)

5 Environmental Engineering, Universidad Nacional José María Arguedas, Andahuaylas 03701, Peru; yuditchoque@gmail.com

6 Department of Environmental Engineering, Universidad Tecnológica de los Andes, Apurímac 03001, Peru; ayma_21@hotmail.com

7 Faculty of Engineering, Universidad Continental, Cusco 12000, Peru; magalyzamalloa@gmail.com (L.M.Z.-P.); ZMILUSKA@HOTMAIL.COM (M.M.Z.-P.)

8 Agroindustrial Engineering, Universidad Nacional de San Antonio Abad del Cusco, Cusco 08000, Peru; miriam.calla@unsaac.edu.pe (M.C.-F.); antonieta.mojo@unsaac.edu.pe (A.M.-Q.)

9 Agroindustrial Research Laboratory, Universidad Nacional José María Arguedas, Andahuaylas 03701, Peru; mirianobregon95@gmail.com

* Correspondence: dchoque@unajma.edu.pe

\begin{abstract}
Edible films prepared from biological materials are being massively used. This study aimed to prepare edible films from native potato starch of the Allcca sipas variety (Solanum tuberosum subsp. Andigena), nopal mucilage (Opuntia ficus indica), and glycerol. Twelve edible films were prepared with starch, mucilage, and glycerin in different proportions by thermosynthesis. It was observed that mucilage and glycerol have a significant direct effect on film solubility and an inverse effect on $\mathrm{a}_{\mathrm{w}}$, while the effect of starch is the opposite. The $\mathrm{a}_{\mathrm{w}}$ ranged from 0.562 to 0.639 . The FTIR analysis showed the interaction of the components in the films being considerably influenced by the addition of mucilage. The TGA/DTA analysis reported low thermal stability in the films, retaining water around $100{ }^{\circ} \mathrm{C}$, and showing a tendency to lose weight when the content of starch is high, while the opposite occurred with the addition of mucilage; it was also observed that around $310^{\circ} \mathrm{C}$, the maximum weight loss was observed between 53.6 and $86.1 \%$. SEM images showed uniform films without cracks. The results are promising and show the possibility of preparing edible films from native potato starch and mucilage.
\end{abstract}

Keywords: solubility; water activity; nopal mucilage; native potato starch; Allcca sipas

\section{Introduction}

In the post-harvest, the conservation of fruits and vegetables are made by edible films, which have become extensively used. Edible films are made from plant and animal materials, allowing to take advantage of its constituents, such as proteins, polysaccharides, lipids, and their mixtures [1]. The environmental friendly aspect of such films has given them an advantage in comparison the films derived from petroleum [2]. These films allow the extension of the shelf life of food, giving it the appearance of freshness, with good shine, 
and color, improving its commercial value through the control of gas transfer and growth of microorganisms [3], that in most cases accelerate their maturity and senescence [1,4,5].

Water activity is one of the important parameters in food preservation, especially in foods with high moisture and nutrient content, which can be attacked by microorganisms, and deteriorate their quality. Coatings have the ability to minimize or eliminate this fact, and this will depend on their composition and formulation; therefore, values lower than 0.65 are adequate to avoid the development of undesirable microorganisms [6].

On the other hand, the response of edible films to changes in temperature to which they may be subjected allows one to evaluate the availability of their constituents, mainly water and volatile compounds, which define the qualities of films. This behavior can be described through thermal analysis; however, the interaction of the constituents depends on the functional groups presented, such groups can be evidenced through an infrared study (IR) and the visualization of the microtopography of the film using scanning electron microscopy (SEM) [7-9].

A nopal (Opuntia ficus indica) is a cactus that grows in soils and demands low amounts of nutrients and humidity. This cactus has a mucilage with good rheological properties [10], and is made up of sugars, such as arabinose, rhamnose, galactose, xylose, pectins, and uronic acids [11,12], with disposition of functional hydroxyls and carbonyl groups, giving it a high ability to bind to polar macromolecules, in other words, creating qualities to form polymeric films $[4,8,13]$. Many attempts have been made to improve the physical and chemical properties of mucilage based on films, by adding carrageenans [14], solvents [15], microencapsulation in gallic acid [14], corn starch [10], pectin [16], polyvinyl alcohol, chitosan, sorbitol, glycerol [13].

The native potato (Solanum tuberosum subsp. Andigena) grows above $3500 \mathrm{~m}$ of altitude and is consumed by local people. This tuber has a high content of dry matter [17] of which starch is found in a higher percentage, with an oval and spherical shape, and a granule size greater than starches from other sources [18]. The native potato starch is constituted by amylose and amylopectin, the latter of which has a branched chain, which confers a greater number of hydroxyl groups and phosphate ester, making it responsible for having a better mechanical behavior [19] especially when linking with other molecules for the preparation of films [20]. Similarly, its low gelatinization temperature and the rheological behavior of pastes and gels allow for film conformation treatments at low temperatures $[19,21,22]$.

The purpose of this work was to prepare an edible film formulated with native potato starch of the Allcca sipas variety, nopal mucilage, and glycerol as a plasticizer, and determine the physical and chemical characterization in order to apply as a coater for fruit and vegetable protection and conservation.

\section{Materials and Methods}

\subsection{Vegetal Material}

The native potato of the Allcca sipas variety (Solanum tuberosum subsp. Andigena) was collected in its commercial maturity state from the cultivation fields of the Chulcuisa town center in May 2018, located at $13^{\circ} 41^{\prime} 01^{\prime \prime} \mathrm{S}, 73^{\circ} 14^{\prime} 20^{\prime \prime} \mathrm{W}$, and $3880 \mathrm{~m}$ of altitude, of the Andahuaylas Province, Peru. The wild cladodes of nopal (Opuntia ficus indica) were collected in Possoccoy area in June 2018, located at $13^{\circ} 35^{\prime} 26.4^{\prime \prime}$ S, $73^{\circ} 27^{\prime} 0.8^{\prime \prime} \mathrm{W}, 2500 \mathrm{~m}$ altitude from the Talavera district, Andahuaylas, Peru.

\subsection{Nopal Mucilage and Starch Extraction}

The starch was obtained by hydroextraction and dried at $45 \pm 2{ }^{\circ} \mathrm{C}$ for $14 \mathrm{~h}$, then it was ground in a planetary ball mill, Resch PM10, at $150 \mathrm{rpm}$ for $3 \mathrm{~min}$ and sieved to $250 \mu \mathrm{m}$. The mucilage was obtained by chopping the nopal cladodes, immersing them in water with a 1:1 ratio. Then, $24 \mathrm{~h}$ later the obtained liquid was treated with ethanol at $96^{\circ}$, in a 3:1 ratio, to extract the precipitated mucilage which was dried at $70{ }^{\circ} \mathrm{C}$ for $24 \mathrm{~h}$. It was 
ground in a planetary ball mill, Resch PM10, at $150 \mathrm{rpm}$ for $3 \mathrm{~min}$ and sieved to $250 \mu \mathrm{m}$, obtaining a fine powder.

\subsection{Formulation of Edible Films}

Films were formulated with native potato starch, powdered mucilage, and glycerol (G) (99.5\%, Scharlau, Barcelona, Spain). A 2\% starch solution (S) and 0.5\% mucilage (M) were mixed, gelled at $70{ }^{\circ} \mathrm{C}$ with continuous stirring for each case. Subsequently, it was allowed to cool down to $40^{\circ} \mathrm{C}$ and mixing was carried out according to the formulations in Table 1 in the order S-G-M. Stirring was constant at $40 \mathrm{rpm}$, maintaining the temperature for $5 \mathrm{~min}$ to guarantee the complete mix. A total of $50 \mathrm{~mL}$ of the mixture was charged in silicone molds, and placed in a forced convection dryer, Binder model FED, Tuttlingen, Germany, at the temperature of each formulation for $24 \mathrm{~h}$.

Table 1. Formulation of edible films.

\begin{tabular}{ccccc}
\hline Formulation & S (\%) & M (\%) & G (\%) & T ( $\left.{ }^{\circ} \mathbf{C}\right)$ \\
\hline F1.50 & 94 & 3 & 3 & 50 \\
F1.60 & 94 & 3 & 3 & 60 \\
F1.70 & 94 & 3 & 3 & 70 \\
\hline F2.50 & 91 & 4 & 5 & 50 \\
F2.60 & 91 & 4 & 5 & 60 \\
F2.70 & 91 & 4 & 5 & 70 \\
F3.50 & 93 & 5 & 2 & 50 \\
F3.60 & 93 & 5 & 2 & 60 \\
F3.70 & 93 & 5 & 2 & 70 \\
\hline F4.50 & 90 & 5 & 5 & 50 \\
F4.60 & 90 & 5 & 5 & 60 \\
F4.70 & 90 & 5 & 5 & 70 \\
\hline
\end{tabular}

Where: F, formulation; S, starch; M, mucilage; G, glycerin; T, temperature.

\subsection{Determination of Solubility and Resistance to Solvents}

A film sample was taken in a ratio of 1 film: 100 solvent $(\mathrm{g} / \mathrm{mL})$, solvents were prepared with hydrochloric acid ( $\mathrm{pH} 4.7)$, potassium hydroxide $(\mathrm{pH} 8.7)$, and ultrapure water; it was allowed to stand for $24 \mathrm{~h}$, and the disintegrated fraction was passed through filter paper and dried at $105^{\circ} \mathrm{C}$ for $24 \mathrm{~h}$. Solubility was expressed in terms of the percentage of dry disintegrated material [1].

For solvent resistance, $0.5 \mathrm{~cm} \times 1.0 \mathrm{~cm}$ films were cut and introduced in $20 \mathrm{~mL}$ of a solvent and left for $24 \mathrm{~h}$ at $20^{\circ} \mathrm{C}$. The solvent media was $0.01 \mathrm{M} \mathrm{HCl}, 0.01 \mathrm{M} \mathrm{NaOH}, 0.01 \mathrm{M}$ $\mathrm{CH}_{3} \mathrm{COOH}$, ethanol at $96^{\circ}$, petroleum ether, and deionized water. It was qualified as highly soluble (HS) when no film particles were observed in the solvent medium; moderately soluble (MS) when small particles of the film without disintegration were evident; low solubility (LS) when the films hardly disintegrated; and not soluble (NS) when the film remained intact in the solvent medium.

\subsection{Determination of Water Activity $\left(a_{w}\right)$}

The samples were previously taken to a desiccator with silica gel for $48 \mathrm{~h}, \mathrm{a}_{\mathrm{w}}$ was determined through the AquaLab 4TEV equipment (Decagon Devices Inc., Washington, DC, USA).

\subsection{FTIR Analysis}

Pressed tablets were prepared, with $0.1 \%$ of the film in $\mathrm{KBr}$ (IR Grade, Darmstadt, Germany), and they were brought to the transmission module of the FTIR spectrometer (Fourier-transform infrared spectroscopy), Thermo Fisher (Waltham, MA, USA), Nicolet is 50 model, in a range of 4000 to $400 \mathrm{~cm}^{-1}$ with a resolution of $4 \mathrm{~cm}^{-1}$. 


\subsection{Thermal Analysis}

The thermal stability of the films was determined with a TGA/DTA (TGA, thermogravimetric analysis, DTA, differential thermal analysis) analyzer model STA PT 1600LINSEIS, Selb, Germany, in air atmosphere with a heating rate of $10^{\circ} \mathrm{C} / \mathrm{min}$, temperature range of 18 to $630^{\circ} \mathrm{C}$, and alumina crucibles $\left(\mathrm{Al}_{2} \mathrm{O}_{3}\right)$ were used as sample carriers.

\subsection{SEM Analysis}

A Quanta 200 model scanning electron microscope (SEM, Thermo Fisher, Waltham, MA, USA) was used. The films were fixed on an adhesive tape and taken to the vacuum chamber of the equipment, and the surface of the biopolymer was recognized through the equipment's software.

\subsection{Statistical Analysis}

The extreme vertices mixture design was used and the data were collected in triplicate. An analysis of variance (ANOVA) was applied, as well as the Tukey's mean test at 5\% significance. Statistica 8.0 software (Statsoft Inc., Tulsa, OK, USA) was used for statistical analysis.

\section{Results and Discussion}

\subsection{Solubility and Resistance to Solvents}

The films subjected to the acid, basic, and neutral media did not report a significant difference in terms of solubility for each formulation in almost all cases ( $p$-value $>0.05$ ), however, this increased slightly at a higher treatment temperature. In Table 2, it is observed that the solubility is in the range of 19.77 to $54.08 \%$. Dick et al. [1] reported solubility of up to $84.5 \%$ for films made with chia seed glycerol mucilage, and González et al. [16] reported $91.04 \%$ for nopal mucilage films, although the solubility behavior will depend on the use that is given to the edible film $[3,23]$.

Table 2. Solubility of prepared edible films in different media (\%).

\begin{tabular}{|c|c|c|c|c|c|c|c|c|c|c|c|c|}
\hline & \multicolumn{4}{|c|}{$\begin{array}{l}\text { Basic Medium } \\
\quad(\mathrm{pH}=8.7)\end{array}$} & \multicolumn{4}{|c|}{$\begin{array}{l}\text { Acidic Medium } \\
\quad(\mathrm{pH}=4.7)\end{array}$} & \multicolumn{4}{|c|}{$\begin{array}{c}\text { Ultrapure Water } \\
(\mathrm{pH}=7.0)\end{array}$} \\
\hline & $\bar{x}$ & \pm & $\mathbf{s}$ & $*$ & $\bar{x}$ & \pm & $\mathrm{s}$ & $*$ & $\bar{x}$ & \pm & $\mathrm{s}$ & * \\
\hline F1.50 & 35.92 & \pm & 1.03 & $\mathrm{~d}$ & 34.46 & \pm & 0.74 & $\mathrm{~d}$ & 34.96 & \pm & 0.50 & $\mathrm{~d}$ \\
\hline F1.60 & 40.36 & \pm & 0.47 & $\mathrm{e}$ & 40.69 & \pm & 0.89 & $\mathrm{~d}, \mathrm{e}$ & 38.15 & \pm & 0.96 & e \\
\hline F1.70 & 40.42 & \pm & 0.62 & $a, b$ & 39.17 & \pm & 1.03 & $\mathrm{~b}$ & 38.51 & \pm & 0.18 & $\mathrm{~b}$ \\
\hline $\mathrm{F} 2.50$ & 26.87 & \pm & 1.72 & c & 23.01 & \pm & 1.15 & $\mathrm{c}$ & 19.77 & \pm & 2.03 & $\mathrm{c}, \mathrm{d}$ \\
\hline F2.60 & 29.30 & \pm & 0.56 & e & 31.29 & \pm & 0.78 & $e, f$ & 27.75 & \pm & 0.65 & $\mathrm{e}$ \\
\hline $\mathrm{F} 2.70$ & 29.67 & \pm & 0.34 & $\mathrm{f}$ & 28.85 & \pm & 0.38 & $\mathrm{~g}$ & 28.54 & \pm & 1.51 & $\mathrm{f}$ \\
\hline F3.50 & 47.87 & \pm & 1.60 & c & 48.43 & \pm & 2.37 & c & 50.19 & \pm & 1.93 & $\mathrm{C}$ \\
\hline F3.60 & 51.65 & \pm & 1.45 & $\mathrm{~b}$ & 54.08 & \pm & 3.69 & $\mathrm{~b}$ & 53.03 & \pm & 0.54 & $a, b$ \\
\hline F3.70 & 50.71 & \pm & 0.77 & $\mathrm{e}$ & 48.63 & \pm & 1.29 & $\mathrm{~d}, \mathrm{e}$ & 48.02 & \pm & 1.27 & $\mathrm{e}$ \\
\hline $\mathrm{F} 4.50$ & 24.03 & \pm & 1.68 & $e, f$ & 21.96 & \pm & 0.67 & $\mathrm{~g}$ & 22.41 & \pm & 0.72 & $\mathrm{f}$ \\
\hline F4.60 & 28.34 & \pm & 1.20 & a & 30.31 & \pm & 1.33 & $\mathrm{a}$ & 26.31 & \pm & 0.66 & a \\
\hline F4.70 & 28.57 & \pm & 1.54 & e & 24.72 & \pm & 1.57 & $f, g$ & 27.46 & \pm & 1.49 & e \\
\hline
\end{tabular}

Where: F, formulation; $\bar{x}$, mean; s, standard deviation. ${ }^{*}$ Different letters indicate significant difference, evaluated through the Tukey test at $5 \%$ significance.

Films with formulation F3 reported higher solubility (Table 2), while formulation F2 and F4 showed lower values; that is, F3 had a high cohesiveness in the polymer matrix. This is attributed to the fact that these formulations have a higher glycerol content that acts as a plasticizer, giving it higher resistance to be dissolved [13,24]. In addition, these formulations contain a lower percentage of $90 \%$ starch, which gives them less capacity to retrograde due to the amylose content $[18,19,25,26]$. This would also be associated with the 
higher percentage of mucilage in the F2 and F4 formulations, as reported by GuadarramaLezama et al. [8], considering that mucilage has a highly branched structure with carboxyl groups, which gives it a higher ability to link and interact with the carboxyl and hydroxyl groups of starch $[4,18]$.

Regarding the resistance to solubility, it was observed that the films subjected to a solution of strong acid $(\mathrm{HCl}, 0.01 \mathrm{M})$ and weak acid $\left(\mathrm{CH}_{3} \mathrm{COOH}, 0.01 \mathrm{M}\right)$ showed similar behavior (Table 3), presenting between moderate and high solubility, the same as for the strong base $(\mathrm{NaOH}, 0.01 \mathrm{M})$. This fact is mainly due to the ease of establishing hydrophilic links of the hydrogen or Van der Walls type between the molecules of the solvent medium, hydrogen ion, and hydroxyls of the acid and base. The partial positive and negative charges that the functional groups of the film present, which are polar nature [8,27], especially glycerol, a small molecule, that is housed in the intermolecular matrix of the film, giving it permeable capacity $[16,28,29]$; therefore, when subjected to organic solvents, such as ethanol and ether, it was observed that the edible films did not show solubility due to their low or null polarity.

Table 3. Solubility resistance in edible films.

\begin{tabular}{|c|c|c|c|c|c|c|}
\hline & $\mathrm{HCl}^{*}(0.01 \mathrm{M})$ & $\mathrm{CH}_{3} \mathrm{COOH}^{* *}(0.01 \mathrm{M})$ & $\mathrm{NaOH} * * *(0.01 \mathrm{M})$ & Ethanol & Ether & Ultrapure Water \\
\hline F1.50 & MS & MS & MS & NS & NS & MS \\
\hline F1.60 & HS & HS & MS & NS & NS & MS \\
\hline $\mathrm{F} 1.70$ & HS & HS & MS & NS & NS & MS \\
\hline F2.50 & MS & MS & MS & NS & NS & LS \\
\hline F2.60 & MS & MS & MS & NS & NS & MS \\
\hline $\mathrm{F} 2.70$ & MS & MS & MS & NS & NS & MS \\
\hline F3.50 & HS & HS & HS & NS & NS & HS \\
\hline F3.60 & HS & HS & HS & NS & NS & HS \\
\hline F3.70 & HS & HS & HS & NS & NS & HS \\
\hline F4.50 & MS & MS & MS & NS & NS & MS \\
\hline F4.60 & MS & MS & MS & NS & NS & MS \\
\hline F4.70 & MS & MS & MS & NS & NS & MS \\
\hline
\end{tabular}

Where: HS, high solubility; MS, moderately soluble; LS, low solubility; NS, non soluble. ${ }^{*}$ Hydrochloric acid, ${ }^{* *}$ acetic acid, *** sodium hydroxide.

\subsection{Water Activity}

Due to the components of the edible films, they would present a matrix with available carbonyl and hydroxyl groups, and probably sugar residues from potato starch and mucilage, increasing the available active hygroscopic sites which would increase the water activity $\left(\mathrm{a}_{\mathrm{w}}\right)$ [30,31]. In Table $4, \mathrm{a}_{\mathrm{w}}$ values ranging from 0.562 to 0.680 for edible film formulations are presented ( $p$-value $<005)$. These values are adequate to inhibit the growth of microorganisms [6,32]. $a_{w}$ was observed to increase slightly with the addition of potato starch and treatment temperature; because the hydrophilic polymeric chains of the starch swell, since they have more water linking groups coming mainly from amylopectin, starch would considerably influence water activity (Figure 1b), as mentioned by Ghanbarzadeh et al. [33], Kibar et al. [34], and Muscat et al. [35]. 
Table 4. Water activity of prepared edible films.

\begin{tabular}{ccccc}
\hline Formulation & & $\mathbf{a}_{\mathbf{w}}$ & & $*$ \\
\hline F1.50 & 0.578 & \pm & 0.007 & $\mathrm{~d}$ \\
F1.60 & 0.619 & \pm & 0.002 & $\mathrm{~b}$ \\
F1.70 & 0.596 & \pm & 0.005 & $\mathrm{c}$ \\
\hline F2.50 & 0.613 & \pm & 0.005 & $\mathrm{~b}$ \\
F2.60 & 0.576 & \pm & 0.004 & $\mathrm{~d}$ \\
F2.70 & 0.586 & \pm & 0.003 & $\mathrm{c}, \mathrm{d}$ \\
\hline F3.50 & 0.562 & \pm & 0.006 & $\mathrm{e}$ \\
F3.60 & 0.639 & \pm & 0.003 & $\mathrm{a}$ \\
F3.70 & 0.615 & \pm & 0.002 & $\mathrm{~b}$ \\
\hline F4.50 & 0.580 & \pm & 0.007 & $\mathrm{~d}$ \\
F4.60 & 0.573 & \pm & 0.002 & $\mathrm{~d}, \mathrm{e}$ \\
F4.70 & 0.580 & \pm & 0.002 & $\mathrm{~d}$
\end{tabular}

Where: $\mathrm{F}$, formulation; $\mathrm{a}_{\mathrm{w}}$, water activity. ${ }^{*}$ Different letters indicate significant difference, evaluated through the Tukey test at $5 \%$ significance.

In contrast, the increase in mucilage decreases $\mathrm{a}_{\mathrm{w}}$ (Figure $1 \mathrm{~b}$ ), this might be due to the fact that the galacturonic acid of the mucilage would not have undergone a substantial change in its structure during the synthesis of the film, since its linear structure makes it less receptive to water molecules [36,37]. This is while the addition of glycerol decreases $\mathrm{a}_{\mathrm{w}}$ (Figure 1b), however Navia et al. [30], Tanada-Palmu et al. [38], Galus et al. [39], and Basiak et al. [40], reported a contrary behavior, this was attributed to the synergy of the components, such as nopal mucilage, and potato starch which is found in a higher percentage (Figure 1a).
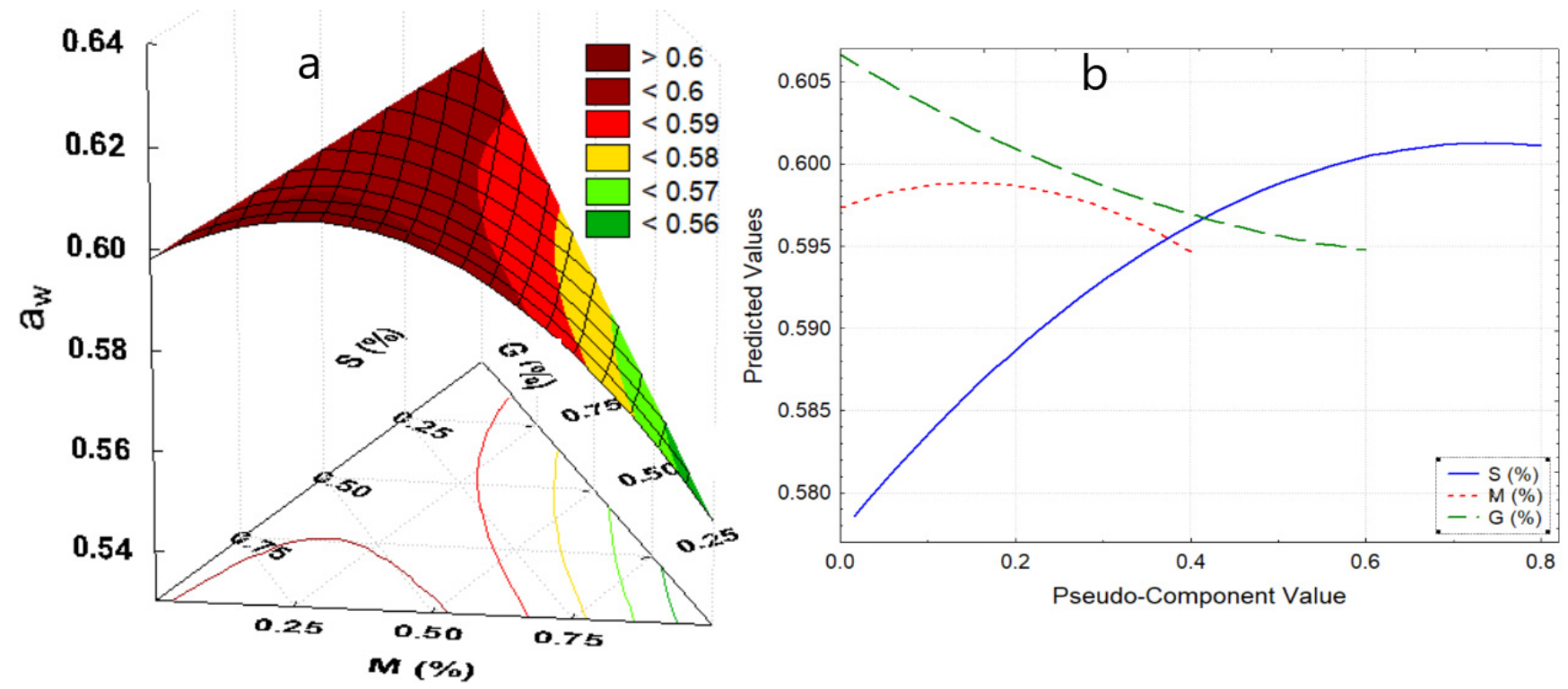

Figure 1. (a) Response surface for $a_{w}$, (b) effects diagram for $a_{w}$. Where: $a_{w}$, water activity; $S$, starch; M, mucilage; G, glycerin.

\subsection{FTIR Analysis}

The FTIR spectra of potato starch and nopal mucilage are affected by the processes of mixing and heat treatment in the synthesis of edible films [41]. This has the capability to modify the molecular interactions of their constituents (stretching, bending, and twisting of chemical bonds), due to changes in the network of hydrogen bonds in the polymer matrix $[20,42]$.

In Figure 2, the spectra of starch of the native potato of the Allca Sipas variety and the nopal mucilage shows an intense band around $3390 \mathrm{~cm}^{-1}$ corresponding to an $-\mathrm{OH}$ 
stretching of the functional groups alcohol and carboxylic acids, and -NH of amides; on the other hand, there is a band around $2930 \mathrm{~cm}^{-1}$ that corresponds to an asymmetric stretch $-\mathrm{CH}_{2}$ being more pronounced for potato starch. Around the $1650 \mathrm{~cm}^{-1}$ band, the torsion and stretching $-\mathrm{OH}$ and $\mathrm{C}=\mathrm{O}$, which corresponds to bound water and amides, was observed as observed more intense for mucilage, and is due to the presence of proteins present $[4,16]$. The range between 1500 and $800 \mathrm{~cm}^{-1}$ is known as the fingerprint of material, and functional groups prevail $-\mathrm{OH}, \mathrm{C}-\mathrm{O},-\mathrm{CH}_{2}, \mathrm{C}-\mathrm{O}-\mathrm{C}$, that includes molecules of sugars, alcohols, and organic acids $[40,41]$ present in potato starch and nopal mucilage, being characteristic for these type of materials $[8,10,18,40]$. On the other hand, it was observed that the mucilage did not show the $925 \mathrm{~cm}^{-1}$ band corresponding to -OH deformation of carboxylic acids, as reported by Guadarrama-Lezama et al. [8].

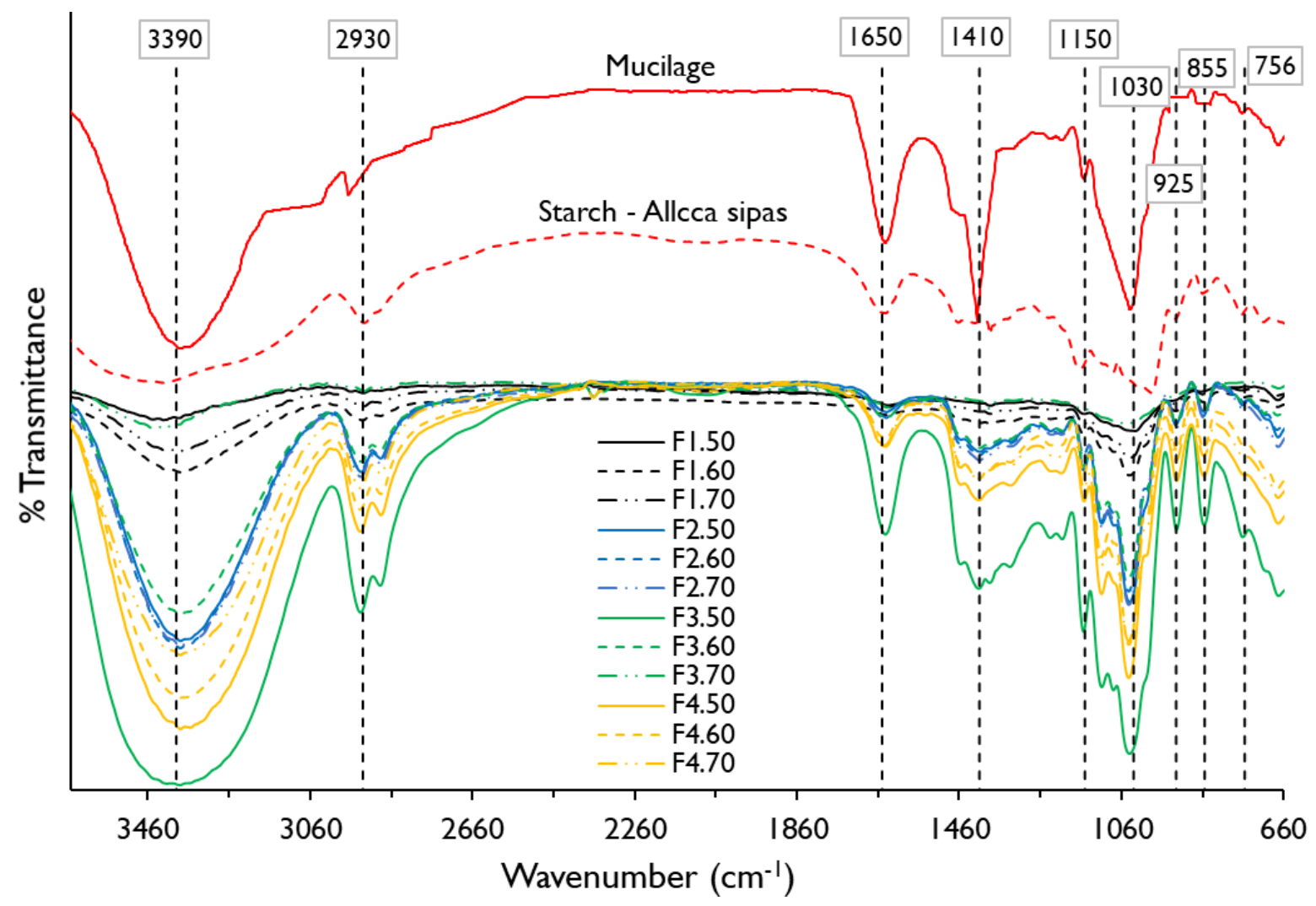

Figure 2. Fourier transform infrared (FTIR) spectra for potato starch, nopal mucilage, and edible films formulations.

When observing the spectrograms of the edible films, it is seen that the polymeric matrix of the different formulations maintain the predominant functional groups $-\mathrm{OH}, \mathrm{C}-\mathrm{O}$, $-\mathrm{NH}, \mathrm{CH} 2, \mathrm{C}=\mathrm{O}, \mathrm{C}-\mathrm{O}-\mathrm{C}$ from potato starch and nopal mucilage, however formulations F1.50, F1.60, and F1.70 do not show the 1410 and $1150 \mathrm{~cm}^{-1}$ band. This is justified by the low percentage of mucilage in these films (3\%) and high starch content (Table 1), which is related to the behavior of water activity (Table 4 , Figure $1 \mathrm{~b}$ ). To these bands, the potato starch shows slight stretching $-\mathrm{OH}, \mathrm{C}-\mathrm{O}$, and $\mathrm{C}-\mathrm{O}-\mathrm{C}$, so it could be assumed that starch has few ether and alcohol groups, as reported by Martinez et al. [18], which is influenced by the treatment temperature [7].

In the same way, it can be seen that all the films show $-\mathrm{OH}$ stretch in the $1030 \mathrm{~cm}^{-1}$ band (Table 5). This is due to the contribution of hydroxyl groups of the glycerol [43,44], which would promote dipole-dipole type hydrogen bonding interactions between starch, mucilage, and glycerol, proving their hydrophilic nature [9]. 
Table 5. FTIR spectra for formulations of edible films, starch, and mucilage.

\begin{tabular}{|c|c|c|c|c|}
\hline Wavenumber $\left(\mathrm{cm}^{-1}\right)$ & Functional Group & Vibration Type & Compound Type & Present in \\
\hline 3390 & $-\mathrm{NH}$ y $-\mathrm{OH}$ & Stretching & $\begin{array}{l}\text { Alcohols, secondary } \\
\text { amide, and carboxylic } \\
\text { acids }\end{array}$ & $\begin{array}{c}\text { All formulations, } \\
\text { starch, and mucilage }\end{array}$ \\
\hline 2930 & $-\mathrm{CH}_{2-}$ & Asymmetric stretching & Methylene groups & $\begin{array}{c}\text { All formulations, } \\
\text { starch, and mucilage }\end{array}$ \\
\hline 1650 & $-\mathrm{OH}, \mathrm{C}=\mathrm{O}$ & Bending, stretching & Water, amide & $\begin{array}{c}\text { F2.50, F2.60, F2.70, } \\
\text { F3.50, F3.60, F3.70, } \\
\text { F4.50, F4.60, F4.70, } \\
\text { starch, and mucilage }\end{array}$ \\
\hline 1410 & $-\mathrm{OH}, \mathrm{C}-\mathrm{O}$ & Stretching & Alcohols & $\begin{array}{c}\text { F2.50, F2.60, F2.70, } \\
\text { F3.50, F3.60, F3.70, } \\
\text { F4.50, F4.60, F4.70, } \\
\text { starch and mucilage }\end{array}$ \\
\hline 1150 & $\mathrm{C}-\mathrm{O}-\mathrm{C}$ & Stretching & Ether & $\begin{array}{c}\text { All formulations, } \\
\text { starch, and mucilage }\end{array}$ \\
\hline 1030 & $\mathrm{C}-\mathrm{O}$ & Stretching & Alcohols & $\begin{array}{c}\text { All formulations, } \\
\text { starch, and mucilage }\end{array}$ \\
\hline 925 & -OH out of plane & Deformation & Carboxylic acids & $\begin{array}{l}\text { All formulations, and } \\
\text { starch }\end{array}$ \\
\hline 855 & $-\mathrm{CH} 2-$ & Deformation & Methylene groups & $\begin{array}{c}\text { All formulations, } \\
\text { starch, and mucilage }\end{array}$ \\
\hline 756 & $\mathrm{C}-\mathrm{O}-\mathrm{C}$ & Stretching & Ether & $\begin{array}{c}\text { All formulations, } \\
\text { starch, and mucilage }\end{array}$ \\
\hline
\end{tabular}

Source: Hu et al. [45], Galicia-García et al. [46], Arief et al. [47].

\subsection{Thermal Analysis}

The TGA analysis shows that the native potato starch presented better thermal stability with a melting temperature $\left(\mathrm{T}_{\mathrm{m}}\right)$ close to $260{ }^{\circ} \mathrm{C}$, while the mucilage showed $\mathrm{T}_{\mathrm{m}}$ around $240{ }^{\circ} \mathrm{C}$ (Figure 3a), this difference is attributed to the fact that the starch has a higher number of free amino groups compared to mucilage (Figure 1). However, mucilage presents better stability to water loss, which manifests up to $80^{\circ} \mathrm{C}$, while starch barely up to $40^{\circ} \mathrm{C}$. This fact is due to the content of heteropolysaccharides (pectins) in the mucilage, so that this content makes it unstable at the fusion temperature $[44,48,49]$.

While the water loss stability of edible films is very low, this is due to the high starch content in the formulations, as reported by Velásquez et al. [50] and López-García et al. [10]. However, F4 presents a slightly higher stability due to the high content of mucilage and glycerol.

The weight loss of the mucilage has three stages, the first comprising from 20 to $240.4{ }^{\circ} \mathrm{C}$ attributed to low molecular weight components, including water, through an endothermic process around $80^{\circ} \mathrm{C}$ (gelatinization) observed in the curve DTA. A second stage occurs between 240.4 to $307.7^{\circ} \mathrm{C}$, with the exothermic process around $300^{\circ} \mathrm{C}$ (Figure 3a), and a third that starts at $427.3^{\circ} \mathrm{C}$, with a tendency to continue decreasing above $600{ }^{\circ} \mathrm{C}$ (Table 6). This fact is possibly due to the decomposition of the mucilage polymeric matrix being resistant, due to its high molecular weight that oscillates between ranging from $13 \times 10^{6}$ to $4.3 \times 10^{6}$ Dalton [51], and the presence of minerals in the form of salts [10]. 

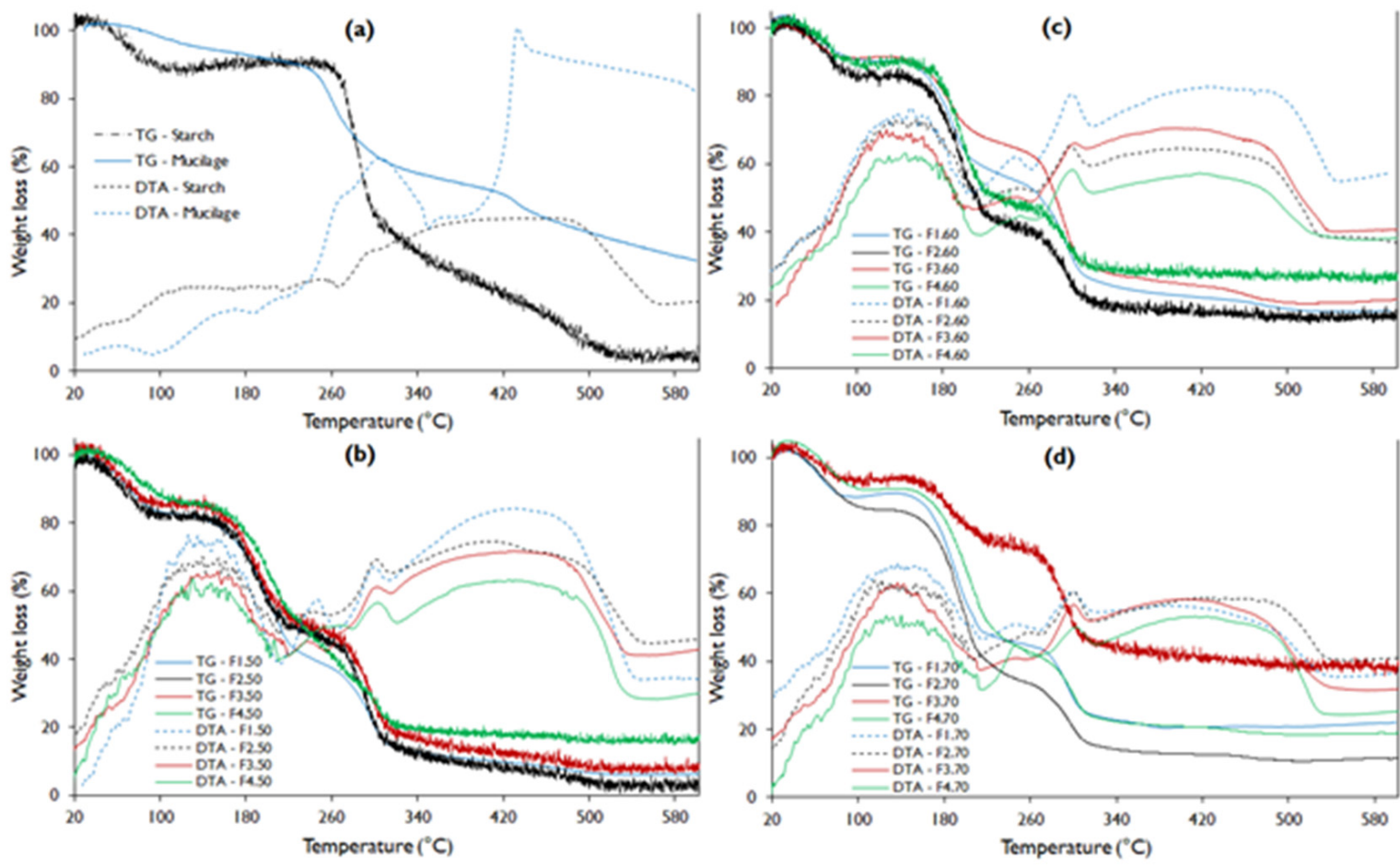

Figure 3. TGA-DTA curve for potato starch, nopal mucilage, and edible film formulations (a). Where: TG, thermogravimetric analysis curve; DTA, differential thermal analysis curve $(\mathbf{b}-\mathbf{d})$.

Table 6. Weight loss and decomposition temperature, determined by TGA-DTA.

\begin{tabular}{|c|c|c|c|c|c|c|c|c|}
\hline & \multicolumn{2}{|c|}{ First Stage } & \multicolumn{2}{|c|}{ Second Stage } & \multicolumn{2}{|c|}{ Third Stage } & \multirow[b]{2}{*}{$\begin{array}{l}\text { Residue } \\
(\%)\end{array}$} & \multirow{2}{*}{$\begin{array}{c}\text { Max. } \\
\text { Weight } \\
\text { Loss (\%) }\end{array}$} \\
\hline & $\begin{array}{c}\text { Weight } \\
\text { Loss (\%) }\end{array}$ & $\mathrm{T}\left({ }^{\circ} \mathrm{C}\right)$ & $\begin{array}{c}\text { Weight } \\
\text { Loss (\%) }\end{array}$ & $\mathrm{T}\left({ }^{\circ} \mathrm{C}\right)$ & $\begin{array}{c}\text { Weight } \\
\text { Loss (\%) }\end{array}$ & $\mathrm{T}\left({ }^{\circ} \mathrm{C}\right)$ & & \\
\hline Starch & 12.0 & 103.6 & 42.9 & 299.2 & 41.8 & 526.8 & 3.2 & 96.8 \\
\hline Mucilage & 11.2 & 240.4 & 25.3 & 307.7 & 12.8 & 427.3 & 50.7 & 49.3 \\
\hline F1.50 & 16.1 & 91.4 & 41.3 & 226.9 & 27.9 & 313.5 & 14.8 & 85.2 \\
\hline $\mathrm{F} 1.60$ & 8.6 & 92.4 & 29.8 & 206.1 & 34.4 & 312.1 & 27.2 & 72.8 \\
\hline $\mathrm{F} 1.70$ & 11.1 & 80.8 & 40.0 & 215.4 & 26.2 & 313.9 & 22.7 & 77.3 \\
\hline $\mathrm{F} 2.50$ & 18.2 & 90.8 & 31.4 & 218.2 & 36.5 & 316.2 & 13.9 & 86.1 \\
\hline $\mathrm{F} 2.60$ & 15.2 & 102.8 & 41.6 & 229.6 & 24.6 & 321.1 & 18.7 & 81.3 \\
\hline $\mathrm{F} 2.70$ & 14.7 & 103.6 & 43.0 & 212.8 & 26.4 & 314.1 & 15.9 & 84.1 \\
\hline F3.50 & 13.8 & 92.9 & 36.5 & 236.8 & 28.8 & 319.5 & 20.9 & 79.1 \\
\hline F3.60 & 8.2 & 85.2 & 22.2 & 213.2 & 37.5 & 310.9 & 31.2 & 68.8 \\
\hline F3.70 & 5.6 & 81.9 & 18.1 & 219.5 & 29.9 & 317.6 & 46.4 & 53.6 \\
\hline $\mathrm{F} 4.50$ & 14.1 & 116.9 & 31.2 & 216.9 & 34.1 & 314.3 & 20.6 & 79.4 \\
\hline $\mathrm{F} 4.60$ & 11.8 & 108.3 & 36.5 & 216.1 & 22.4 & 316.4 & 29.3 & 70.7 \\
\hline $\mathrm{F} 4.70$ & 9.3 & 104.4 & 41.9 & 227.4 & 25.1 & 318.0 & 23.8 & 76.2 \\
\hline
\end{tabular}

Where: F, formulation; $\mathrm{T}$, temperature.

The potato starch presented a zone of 20 to $103.6^{\circ} \mathrm{C}$ that is attributed to the loss of water representing $12.0 \%$ of weight, through an endothermic process around $70{ }^{\circ} \mathrm{C}$ (gelatinization), which is characteristic for these materials $[19,21]$. Another range from 103.6 to $299.2{ }^{\circ} \mathrm{C}$ in this zone, the decomposition of carbohydrates and peptides low molecular weight is considered, which represents $42.9 \%$ of weight. The third stage from 299.2 to $526.8^{\circ} \mathrm{C}(41.8 \%)$ that corresponds to the material degradation zone, that is, the decomposition of the polymeric matrix of starch and high molecular weight polysaccharides which occurs above $320^{\circ} \mathrm{C}[1,50,52]$. 
Regarding the thermograms of the films, it is evident that they do not have a gelatinization zone in the DTA curve (Figure $3 b-d$ ) compared to starch and mucilage. This is because they present glycerin in their composition, which is a plasticizer. It is also observed that they present three well-defined sections corresponding to exothermic changes.

The first zone, between 20 to $116.9^{\circ} \mathrm{C}$, corresponds to the elimination of free and weakly bound water, which represents between 5.6 to $18.2 \%$ of the lost weight, which occurs around $100{ }^{\circ} \mathrm{C}$ for films. The weight loss is mainly due to the addition of glycerin, and to a medium extent to the increase in starch (Figure 4a). This fact is attributed to a large number of active sites with -OH groups that they possess, conferring high hygroscopic capacity. On the other hand, the addition of nopal mucilage allows the maintenance of humidity in the edible film (Figure $4 b$ ).
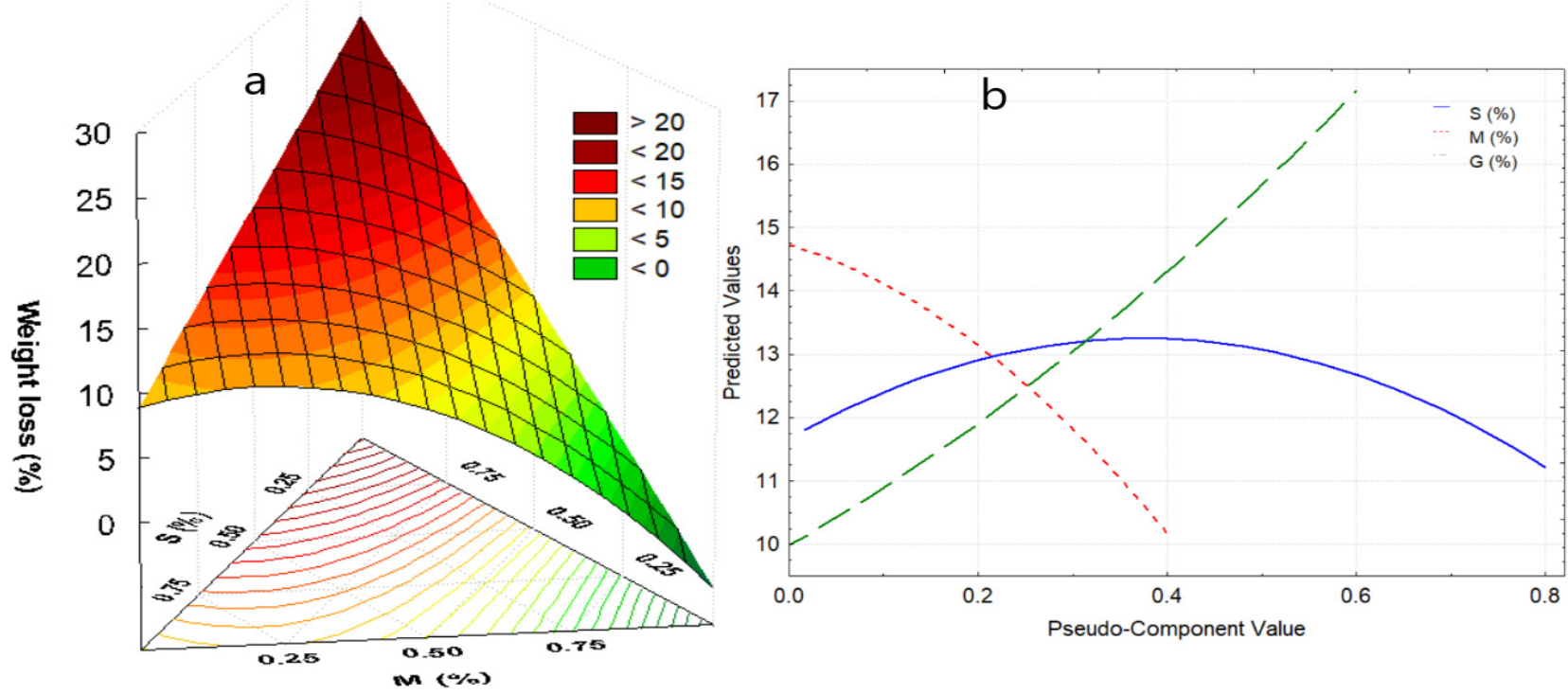

Figure 4. (a) Response surface for weight loss in the first stage, (b) effects diagram for weight loss in the first stage. Where: $\mathrm{S}$, starch; M, mucilage; G, glycerin.

In the second stage, the decomposition of carbohydrates and peptides occurs in a second exothermic stage between 116.9 and $236.8^{\circ} \mathrm{C}$, where the films maintain their structure and the $\mathrm{C}-\mathrm{O},-\mathrm{OH},-\mathrm{COO}-$ interaction bonds are found still constituted. At this stage, an intermediate plateau that corresponds to changes in characteristic polymorphism in biopolymers is observed in all TGA curves $[1,53,54]$, and is due to the existence of different conformers of the same molecule. A third exothermic stage ranging from 236.8 to $321.1^{\circ} \mathrm{C}$, in which the decomposition of polysaccharides (pectins, cellulose, fibers) and high molecular weight proteins occurs, that is, the decomposition of functional groups of tertiary amines and carbonyls (as evidenced in the spectrograms of Figure 1), giving rise to the formation of $\mathrm{CO}_{2}, \mathrm{NO}_{2}$, and $\mathrm{SO}_{2}$, with oxidation and total decomposition of organic matter $[55,56]$.

Above $500{ }^{\circ} \mathrm{C}$, a stabilization of the DTA curve is evident, which corresponds to endothermic crystallization that allows the formation of mineral salts and ashes $[50,57]$. This represents 13.9 to $23.8 \%$ of the residues, and a similar behavior was reported by Dick et al. [1], López-García et al. [10], and Guadarrama-Lezama et al. [8].

Thermograms show that F2 formulations reported higher water loss (Figure 3b-d), and that it decreases with treatment temperatures from 18.2 to $14.7 \%$ (Table 6), while formulation F3 reported lower weight loss values from 13.8 to $5.6 \%$. This fact is attributed to the glycerin content, presenting an inverse effect with the weight loss of the film, as observed by López-García et al. [10].

When the starch proportion increases, there is a great loss of weight in the first stage, and the same behavior was observed for the second stage. In the third stage, polysac- 
charides and molecules of high molecular weight are decomposed, which is attributed to starch and part of mucilage, and correspond to formulation F1 ( $94 \%$ starch and 3\% glycerol) and F3 (93\% starch and $2 \%$ of glycerol); while the maximum amount of weight loss was obtained for formulation F1 and the lowest for F4 (90\% starch, 5\% mucilage, 5\% glycerol). That is to say, the higher the content of mucilage in the film, the less weight loss occurs, since it could present more mineral salts. The same behavior was observed by GuadarramaLezama et al. [8], López-García et al. [10], and Gheribi et al. [58].

\subsection{SEM Analysis}

In Figure 5, the photomicrograph of the native potato starch Allcca sipas is observed, whose granules have oval shapes of different sizes less than $25 \mu \mathrm{m}$, while the dehydrated nopal mucilage presented in the form of amorphous crystals. This is due to the content of calcium and potassium salts [59].

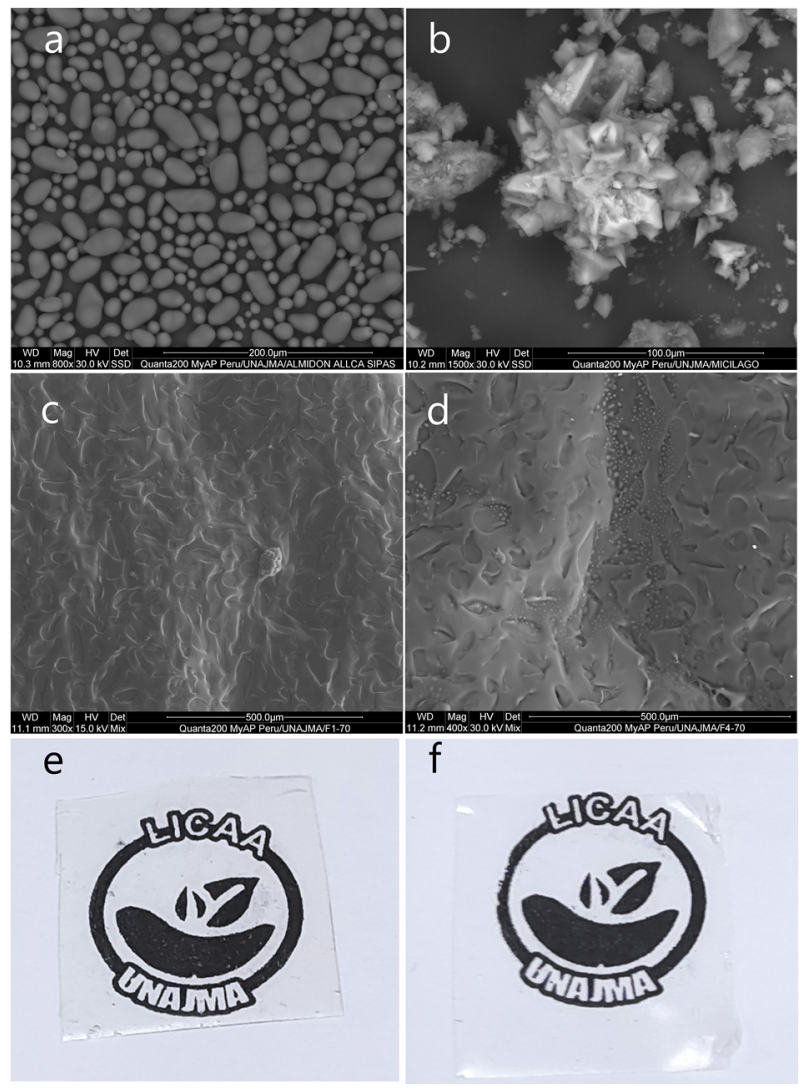

Figure 5. (a) SEM image for native potato starch Allcca sipas, (b) SEM image for dehydrated nopal mucilage, (c) SEM image for F1-70, (d) SEM image for F4-70, (e) edible film F1-70, (f) edible film F4-70.

SEM analysis was considered for the films whose formulations were extreme, F1-70 ( $94 \%$ S, 3\% M, 3\% G) and F4-70 (90\% S, 5\% M, 5\% G), and it was observed that the films were compact, translucent, and without cracks in both formulations (Figure 5e,f). However, the surfaces presented with indentations which were smaller for F1-70 (Figure 4), and this is due to the loss of water during the thermomolding process, and related to the higher starch content, which traps more water, as reported by Zhao et al. [20], Andreuccetti et al. [22], Tosif et al. [53], Andreuccetti et al. [60], and Soukoulis et al. [61]. On the other hand, small bubbles were observed in F4-70, and this is because the mucilage retains interstitial water in the film. Furthermore, during the thermomolding process, the water tries to escape by steam action, however the plasticizing effect of glycerin and starch act as a barrier in the film matrix, forming small pockets [62-64]. 


\section{Conclusions}

The increase in mucilage of nopal and glycerol in edible films decreases the solubility, while the addition of potato starch and the increase in the synthesis temperature greatly increases the solubility, being between medium and high solubility in acidic medium, basic and water, and completely insoluble in non-polar solvents. Edible films show adequate values of water activity for packing food, which increases significantly with the addition of potato starch and treatment temperature, while the addition of mucilage and glycerol slightly decrease $\mathrm{a}_{\mathrm{w}}$. The FTIR analysis showed the interaction of the components of the edible films, preserving their functional groups and being considerably influenced by the addition of nopal mucilage. The TGA-DTA study revealed that the edible films have low thermal stability, retain water around $100{ }^{\circ} \mathrm{C}$, and that the higher starch content reported greater weight loss by thermal decomposition, with the opposite happening with the addition of mucilage. The found results allow us to establish that the synthesized edible films can be used as a packing material, besides having an attractive nutritional contribution due to the conservation of their constituents and functional groups, and have adequate thermal stability as a food coating.

Author Contributions: Conceptualization, D.C.-Q. and S.F.; methodology, C.A.L.-S., H.P.-R. and A.M.-Q.; software, Y.C.-Q.; validation, F.T.-P., M.E.O.-Y. and M.M.Z.-P.; formal analysis, B.S.R.-P., Y.C.-Q. and A.M.S.-R.; investigation, D.C.-Q., C.A.L.-S., B.S.R.-P., H.P.-R., A.M.S.-R., L.M.Z.-P. and M.C.-F.; data curation, M.C.-F.; writing-original draft preparation, D.C.-Q.; writing-review and editing, D.C.-Q., S.F. and L.M.Z.-P.; supervision, D.C.-Q.; project administration, F.T.-P.; M.E.O.-Y. All authors have read and agreed to the published version of the manuscript.

Funding: This research was funded by Vicepresidencia de Investigación de la Universidad Nacional José María Arguedas, Andahuaylas, Apurímac, Perú.

Institutional Review Board Statement: Not applicable.

Informed Consent Statement: Not applicable.

Data Availability Statement: The data presented in this study are available in this same article.

Acknowledgments: The authors would like to thank the Vice Presidency of Research of the Universidad Nacional José María Arguedas, for the financing and use of the water analysis and control research laboratory.

Conflicts of Interest: The authors declare no conflict of interest.

\section{References}

1. Dick, M.; Costa, T.M.H.; Gomaa, A.; Subirade, M.; Rios, A.D.O.; Flôres, S.H. Edible film production from chia seed mucilage: Effect of glycerol concentration on its physicochemical and mechanical properties. Carbohydr. Polym. 2015, 130, 198-205. [CrossRef]

2. Romero-Bastida, C.A.; Zamudio-Flores, P.B.; Bello-Pérez, L.A. Antimicrobianos en películas de almidón oxidado de plátano: Efecto sobre la actividad antibacteriana, microestructura, propiedades mecánicas y de barrera. Rev. Mex. Ing. Quím. 2011, 10, $445-453$.

3. Fernández, D.; Bautista, S.; Fernández, D.; Ocampo, A.; García, A.; Falcón, A. Eatable films and coverings: A favorable alternative in the postharvesIng. conservation of fruits and vegetables. Rev. Cienc. Téc. Agropecu. 2015, 24, 52-57.

4. Espino-Díaz, M.; Ornelas-Paz, J.D.J.; Martínez-Téllez, M.A.; Santillán, C.; Barbosa-Cánovas, G.V.; Zamudio-Flores, P.B.; Olivas, G.I. Development and Characterization of Edible Films Based on Mucilage of Opuntia ficus-indica (L.). J. Food Sci. 2010, 75, E347-E352. [CrossRef] [PubMed]

5. Din, A.; Nadeem, M.; Khan, M.R.; Shabbir, M.A. Development and application of edible skin coatings to improve the quality of kinnow during storage. Acta Sci. Technol. 2015, 37, 111. [CrossRef]

6. Guldas, M.; Bayizit, A.A.; Yilsay, T.O.; Yilmaz, L. Effects of edible film coatings on shelf-life of mustafakemalpasa sweet, a cheese based dessert. J. Food Sci. Technol. 2010, 47, 476-481. [CrossRef] [PubMed]

7. Wang, B.; Xu, F.; Zong, P.; Zhang, J.; Tian, Y.; Qiao, Y. Effects of heating rate on fast pyrolysis behavior and product distribution of Jerusalem artichoke stalk by using TG-FTIR and Py-GC/MS. Renew. Energy 2019, 132, 486-496. [CrossRef]

8. Guadarrama-Lezama, A.Y.; Castaño, J.; Velazquez, G.; Carrillo-Navas, H.; Alvarez-Ramírez, J. Effect of nopal mucilage addition on physical, barrier and mechanical properties of citric pectin-based films. J. Food Sci. Technol. 2018, 55, 3739-3748. [CrossRef] [PubMed] 
9. Liu, P.; Xie, F.; Li, M.; Liu, X.; Yu, L.; Halley, P.J.; Chen, L. Phase transitions of maize starches with different amylose contents in glycerol-water systems. Carbohydr. Polym. 2011, 85, 180-187. [CrossRef]

10. López-García, F.; Jiménez-Martínez, C.; Guzmán-Lucero, D.; Maciel-Cerda, A.; Delgado-Macuil, R.; Cabrero-Palomino, D.; Terrés-Rojas, E.; Arzate-Vázquez, I. Physical and chemical characterization of a biopolymer film made with corn starch and nopal xoconostle (Opuntia joconsotle) mucilage. Rev. Mex. Ing. Quím. 2017, 16, 147-158. [CrossRef]

11. Dominguez-Martinez, B.M.; Martínez-Flores, H.E.; Berrios, J.D.J.; Otoni, C.G.; Wood, D.F.; Velazquez, G. Physical Characterization of Biodegradable Films Based on Chitosan, Polyvinyl Alcohol and Opuntia Mucilage. J. Polym. Environ. 2016, $25,683-691$. [CrossRef]

12. Matsuhiro, B.; Lillo, L.E.; Sáenz, C.; Urzúa, C.C.; Zárate, O. Chemical characterization of the mucilage from fruits of Opuntia ficus indica. Carbohydr. Polym. 2006, 63, 263-267. [CrossRef]

13. Gheribi, R.; Khwaldia, K. Cactus Mucilage for Food Packaging Applications. Coatings 2019, 9, 655. [CrossRef]

14. Medina-Torres, L.; García-Cruz, E.; Calderas, F.; González-Laredo, R.F.; Sanchez-Olivares, G.; Gallegos-Infante, J.; Guzmán, N.E.R.; Rodríguez-Ramírez, J. Microencapsulation by spray drying of gallic acid with nopal mucilage (Opuntia ficus-indica). LWT 2013, 50, 642-650. [CrossRef]

15. Del-Valle, V.; Hernández-Muñoz, P.; Guarda, A.; Galotto, M. Development of a cactus-mucilage edible coating (Opuntia ficus indica) and its application to extend strawberry (Fragaria ananassa) shelf-life. Food Chem. 2005, 91, 751-756. [CrossRef]

16. Sandoval, D.C.G.; Sosa, B.L.; Martínez-Ávila, G.C.G.; Fuentes, H.R.; Abarca, V.H.A.; Rojas, R. Formulation and Characterization of Edible Films Based on Organic Mucilage from Mexican Opuntia ficus-indica. Coatings 2019, 9, 506. [CrossRef]

17. Diez, C.A.; Lopéz, S.E.; Zavaleta, C.R.; Rodriguez, M.Y.; Huayanay, J.P. Quantification of anti-cancer principles of varieties native potatoe of colored pulp la Libertad region to industrial processing. J. Pueblo Cont. 2013, 24, 425-431.

18. Martínez, P.; Peña, F.; Bello-Pérez, L.A.; Núñez-Santiago, C.; Yee-Madeira, H.; Velezmoro, C. Physicochemical, functional and morphological characterization of starches isolated from three native potatoes of the Andean region. Food Chem. X 2019, 2, 100030. [CrossRef] [PubMed]

19. Vargas, G.; Martínez, P.; Velezmoro, C. Functional properties of potato (Solanum tuberosum) starch and its chemical modification by acetylation. Sci. Agropecu. 2016, 7, 223-230. [CrossRef]

20. Zhao, Y.; Li, B.; Li, C.; Xu, Y.; Luo, Y.; Liang, D.; Huang, C. Comprehensive Review of Polysaccharide-Based Materials in Edible Packaging: A Sustainable Approach. Foods 2021, 10, 1845. [CrossRef] [PubMed]

21. Valcárcel-Yamani, B.; Rondan-Sanabria, G.G.; Finardi-Filho, F. The physical, chemical and functional characterization of starches from Andean tubers: Oca (Oxalis tuberosa Molina), olluco (Ullucus tuberosus Caldas) and mashua (Tropaeolum tuberosum Ruiz \& Pavón). Braz. J. Pharm. Sci. 2013, 49, 453-464. [CrossRef]

22. Andreuccetti, C.; Galicia-García, T.; Martínez-Bustos, F.; Grosso, R.F.; González-Núñez, R. Effects of Nopal Mucilage (Opuntia ficus-indica) as Plasticizer in the Fabrication of Laminated and Tubular Films of Extruded Acetylated Starches. Int. J. Polym. Sci. 2021, 2021, 6638756. [CrossRef]

23. Galindez, A.; Daza, L.D.; Homez-Jara, A.; Eim, V.S.; Váquiro, H.A. Characterization of ulluco starch and its potential for use in edible films prepared at low drying temperature. Carbohydr. Polym. 2019, 215, 143-150. [CrossRef]

24. Damas, M.S.P.; Junior, V.A.P.; Nishihora, R.K.; Quadri, M.G.N. Edible films from mucilage of C ereus hildmannianus fruits: Development and characterization. J. Appl. Polym. Sci. 2017, 134, 45223. [CrossRef]

25. Sandhu, K.; Singh, N. Some properties of corn starches II: Physicochemical, gelatinization, retrogradation, pasting and gel textural properties. Food Chem. 2007, 101, 1499-1507. [CrossRef]

26. Ayquipa-Cuellar, E.; Salcedo-Sucasaca, L.; Azamar-Barrios, J.A.; Chaquilla-Quilca, G. Assessment of Prickly Pear Peel Mucilage and Potato Husk Starch for Edible Films Production for Food Packaging Industries. Waste Biomass-Valorization 2021, 12, 321-331. [CrossRef]

27. Turhan, K.; Şahbaz, F. Water vapor permeability, tensile properties and solubility of methylcellulose-based edible films. J. Food Eng. 2004, 61, 459-466. [CrossRef]

28. Rodríguez, M.; Osés, J.; Ziani, K.; Maté, J.I. Combined effect of plasticizers and surfactants on the physical properties of starch based edible films. Food Res. Int. 2006, 39, 840-846. [CrossRef]

29. Mendoza, B.; Hernandez, E.M.; Romo, L.D.; Vargas, A.; Cervantes, J.A.; Fernandez, A.G.E. Edible films based on chayotextle starch and its effect on the shelf life of apples. J. Appl. Biotechnol. Bioeng. 2021, 8, 36-40. [CrossRef]

30. Navia, D.; Ayala, A.; Villada, H.S. Adsorption isotherms of cassava flour bioplastics compression molded. Biotecnol. Sect. Agropecu. Agroind. 2011, 9, 77-87.

31. Quispe, D.C.; Samanez, C.A.L.; Pacheco, B.S.R.; Taipe-Pardo, F.; Peralta-Guevara, D.E.; Reynoso, A.M.S. Evaluación de las isotermas de sorción de granos y harina de kiwicha (Amaranthus caudatus). Rev. ION 2018, 31, 67-81. [CrossRef]

32. Guillard, V.; Broyart, B.; Bonazzi, C.; Guilbert, S.; Gontard, N. Effect of Temperature on Moisture Barrier Efficiency of Monoglyceride Edible Films in Cereal-Based Composite Foods. Cereal Chem. J. 2004, 81, 767-771. [CrossRef]

33. Ghanbarzadeh, B.; Almasi, H.; Entezami, A.A. Improving the barrier and mechanical properties of corn starch-based edible films: Effect of citric acid and carboxymethyl cellulose. Ind. Crops Prod. 2011, 33, 229-235. [CrossRef]

34. Kibar, E.A.A.; Us, F. Thermal, mechanical and water adsorption properties of corn starch-carboxymethylcellulose/methylcellulose biodegradable films. J. Food Eng. 2013, 114, 123-131. [CrossRef] 
35. Muscat, D.; Adhikari, B.; Chaudhary, D.S. Comparative study of film forming behaviour of low and high amylose starches using glycerol and xylitol as plasticizers. J. Food Eng. 2012, 109, 189-201. [CrossRef]

36. Shih, F.; Daigle, K.; Champagne, E. Effect of rice wax on water vapour permeability and sorption properties of edible pullulan films. Food Chem. 2011, 127, 118-121. [CrossRef]

37. Al-Hassan, A.; Norziah, M. Starch-gelatin edible films: Water vapor permeability and mechanical properties as affected by plasticizers. Food Hydrocoll. 2012, 26, 108-117. [CrossRef]

38. Tanada-Palmu, P.S.; Grosso, C.R. Development and characterization of edible films based on gluten from semi-hard and soft Brazilian wheat flours (development of films based on gluten from wheat flours). Food Sci. Technol. 2003, 23, 264-269. [CrossRef]

39. Galus, S.; Turska, A.; Lenart, A. Sorption and wetting properties of pectin edible films. Czech J. Food Sci. 2012, 30, 446-455. [CrossRef]

40. Basiak, E.; Lenart, A.; Debeaufort, F. How Glycerol and Water Contents Affect the Structural and Functional Properties of Starch-Based Edible Films. Polymers 2018, 10, 412. [CrossRef]

41. Durazzo, A.; Kiefer, J.; Lucarini, M.; Camilli, E.; Marconi, S.; Gabrielli, P.; Aguzzi, A.; Gambelli, L.; Lisciani, S.; Marletta, L. Qualitative Analysis of Traditional Italian Dishes: FTIR Approach. Sustainability 2018, 10, 4112. [CrossRef]

42. Pelissari, F.; Andrade-Mahecha, M.M.; Sobral, P.J.D.A.; Menegalli, F.C. Isolation and characterization of the flour and starch of plantain bananas (Musa paradisiaca). Starch-Starke 2012, 64, 382-391. [CrossRef]

43. Jiménez, A.; Fabra, M.J.; Talens, P.; Chiralt, A. Phase transitions in starch based films containing fatty acids. Effect on water sorption and mechanical behaviour. Food Hydrocoll. 2013, 30, 408-418. [CrossRef]

44. Nesic, A.; Ružić, J.; Gordic, M.; Ostojic, S.; Micić, D.; Onjia, A. Pectin-polyvinylpyrrolidone films: A sustainable approach to the development of biobased packaging materials. Compos. Part B Eng. 2017, 110, 56-61. [CrossRef]

45. Hu, Y.; Wang, Q.; Tang, M. Preparation and properties of Starch-g-PLA/poly(vinyl alcohol) composite film. Carbohydr. Polym. 2013, 96, 384-388. [CrossRef] [PubMed]

46. Galicia-García, T.; Martínez-Bustos, F.; Jiménez-Arevalo, O.; Martínez, A.; Ibarra-Gómez, R.; Gaytán-Martínez, M.; MendozaDuarte, M. Thermal and microstructural characterization of biodegradable films prepared by extrusion-calendering process. Carbohydr. Polym. 2011, 83, 354-361. [CrossRef]

47. Arief, V.O.; Trilestari, K.; Sunarso, J.; Indraswati, N.; Ismadji, S. Recent Progress on Biosorption of Heavy Metals from Liquids Using Low Cost Biosorbents: Characterization, Biosorption Parameters and Mechanism Studies. CLEAN-Soil Air Water 2008, 36, 937-962. [CrossRef]

48. Seslija, S.; Spasojević, P.; Panić, V.; Dobrzyńska-Mizera, M.; Immirzi, B.; Stevanović, J.; Popović, I. Physico-chemical evaluation of hydrophobically modified pectin derivatives: Step toward application. Int. J. Biol. Macromol. 2018, 113, 924-932. [CrossRef]

49. López, D.F.; Osorio, O.; Checa, O.E. Propiedades Mecánicas de un Material de Pectina para Revestimiento de Fibras Naturales Utilizadas en Aplicaciones Agrícolas. Inf. Tecnol. 2019, 30, 189-198. [CrossRef]

50. Herrera, J.D.V.; Aguirre, J.C.L.; Castaño, V.D.Q. Physical-chemical characteristics determination of potato (Solanum phureja Juz. \& Bukasov) starch. Acta Agron. 2017, 66, 323-330. [CrossRef]

51. Salehi, E.; Emam-Djomeh, Z.; Askari, G.; Fathi, M. Opuntia ficus indica fruit gum: Extraction, characterization, antioxidant activity and functional properties. Carbohydr. Polym. 2019, 206, 565-572. [CrossRef] [PubMed]

52. Huang, M.; Yu, J.; Ma, X. Ethanolamine as a novel plasticiser for thermoplastic starch. Polym. Degrad. Stab. 2005, 90, 501-507. [CrossRef]

53. Adam, A.M.A.; Altalhi, T.A.; El-Megharbel, S.M.; Saad, H.A.; Refat, M.S. Using a Modified Polyamidoamine Fluorescent Dendrimer for Capturing Environment Polluting Metal Ions $\mathrm{Zn}^{2+}, \mathrm{Cd}^{2+}$, and $\mathrm{Hg}^{2+}$ : Synthesis and Characterizations. Crystals 2021, 11, 92. [CrossRef]

54. Gómez-Aldapa, C.A.; Velazquez, G.; Gutiérrez, M.C.; Castro-Rosas, J.; Jiménez-Regalado, E.J.; Aguirre-Loredo, R.Y. Characterization of Functional Properties of Biodegradable Films Based on Starches from Different Botanical Sources. Starch-Starke 2020, 72, 1900282. [CrossRef]

55. Alarcon, R.T.; Holanda, B.B.D.C.; De Oliveira, A.R.; Magdalena, A.G.; Bannach, G. Production and Characterization of the New Thermoplastic Polymer by Linseed Oil and Glycerol Following Green Chemistry Principles. Rev. Virtual Quím. 2017, 9, 163-175. [CrossRef]

56. Niu, X.; Ma, Q.; Li, S.; Wang, W.; Ma, Y.; Zhao, H.; Sun, J.; Wang, J. Preparation and Characterization of Biodegradable Composited Films Based on Potato Starch/Glycerol/Gelatin. J. Food Qual. 2021, 2021, 6633711. [CrossRef]

57. Dries, D.; Gomand, S.; Goderis, B.; Delcour, J. Structural and thermal transitions during the conversion from native to granular cold-water swelling maize starch. Carbohydr. Polym. 2014, 114, 196-205. [CrossRef] [PubMed]

58. Gheribi, R.; Puchot, L.; Verge, P.; Jaoued-Grayaa, N.; Mezni, M.; Habibi, Y.; Khwaldia, K. Development of plasticized edible films from Opuntia ficus-indica mucilage: A comparative study of various polyol plasticizers. Carbohydr. Polym. 2018, 190, $204-211$. [CrossRef]

59. Sepúlveda, E.; Sáenz, C.; Aliaga, E.; Aceituno, C. Extraction and characterization of mucilage in Opuntia spp. J. Arid. Environ. 2007, 68, 534-545. [CrossRef]

60. Andreuccetti, C.; Carvalho, R.A.; Galicia-García, T.; Martinez-Bustos, F.; González-Núñez, R.; Grosso, C.R. Functional properties of gelatin-based films containing Yucca schidigera extract produced via casting, extrusion and blown extrusion processes: A preliminary study. J. Food Eng. 2012, 113, 33-40. [CrossRef] 
61. Soukoulis, C.; Behboudi-Jobbehdar, S.; Yonekura, L.; Parmenter, C.; Fisk, I.D. Stability of Lactobacillus rhamnosus GG in prebiotic edible films. Food Chem. 2014, 159, 302-308. [CrossRef] [PubMed]

62. Gutiérrez, T.J.; Tapia, M.S.; Pérez, E.; Famá, L. Edible films based on native and phosphated 80:20 waxy: Normal corn starch. Starch-Starke 2015, 67, 90-97. [CrossRef]

63. Zhao, Q.; Dong, B.; Chen, J.; Zhao, B.; Wang, X.; Wang, L.; Zha, S.; Wang, Y.; Zhang, J.; Wang, Y. Effect of drying methods on physicochemical properties and antioxidant activities of wolfberry (Lycium barbarum) polysaccharide. Carbohydr. Polym. 2015, 127, 176-181. [CrossRef]

64. Luna-Sosa, B.; Martínez-Ávila, G.C.G.; Rodríguez-Fuentes, H.; Azevedo, A.G.; Pastrana, L.M.; Rojas, R.; Cerqueira, M. PectinBased Films Loaded with Hydroponic Nopal Mucilages: Development and Physicochemical Characterization. Coatings 2020, 10, 467. [CrossRef] 